\title{
A.V. ALLAHVERDIYEV
}

\author{
Alovsat Vilayet Allahverdiyev, Ph.D. in Law, Lecturer \\ of Baku State University*
}

ORCID: 0000-0001-9442-3853

\section{DEFINING WAR CRIMES: A LOOK TO THE PROSECUTION BY INTERNATIONAL CRIMINAL JUDICIAL BODIES}

Formulation of the problem. One of the fundamental features of the international law is its effectiveness. Particular attention in this regard is centralized on the international legal responsibility, prosecution of international crimes and punishment of perpetrators. Among others, the painful question of war crimes and universally unresolved issue of international prosecution is still waiting for systematic regulation. Crimes against international peace and security have existed throughout history and have become an insurmountable problem. Special concerns are addressed to war crimes due to their high level of danger and low level of efficient prosecution. Terror and wars as well as their consequences have always been frightening for the international community. In the light of hybrid armed or military conflicts, international war crimes get more vogue nature and proper chance to be hidden. In this respect, the relevance of the topic can be explained by the mere fact that a new theoretical-academic approach is needed to define international war crimes, understand their character and to make an attempt to detect primary gaps in international prosecution in order to re-establish the international law of justice.

Analysis of recent research and publications. Some problems related to the introduced subject have been investigated in national law by scholars such as A.I. Aliyev, R.K. Mammadov, S.T. Samedova, R.F. Mammadov and others. Particular attention should be paid to the scientific work "Azerbaijan in the target of international crimes: legal analysis" of Prof. Amir Aliyev, who produced the latest and the most systematic legal overview of war crimes committed in the territory of Western Azerbaijan, Garabag as well as in the all Post-Soviet area. Fruitful scientific analysis has been also done by the experts of international bodies such the United Nations, the International Criminal Court, the Council of Europe, etc. what have been benefitted from in the current study too.

Formulation of the academic purpose. Taking into account the noted concerns about the theory and practice of war crimes, the purpose of the article is to elaborate and improve the conceptual basis of war crimes, study the difficulties of international criminal punishment and search for improvements.

Presentation of main material. Despite the progressive development of modern international law, war crimes have further been "improved", manifested themselves in new forms, and infringed the legitimate interests of states. Practice of latest armed conflicts prove that the warring parties are not eager to recognize each other's legitimate positions and do not follow the simple rules of international humanitarian law. The destruction of historical and cultural monuments, the violence and torture of civilians, and their killings have been described as war crimes, and in very few cases perpetrators have been punished and more oftenly gone unpunished. Certain actions that have already become history are very clear proof of this argument. For example, the London International Assembly, which began its work in the autumn of 1941 to deal with the crimes committed by the German Nazis, referred to the horrific acts of World War I and stressed the failue of the punishment for war crimes of WWI. ${ }^{1}$ The proposals and recommendations submitted by the Assembly stated that attention should be paid not only to violations of the day-to-day rules of war, but also to other serious crimes committed by criminals who were not punished by domestic law during the war.

Following the proposals of the International London Assembly, in 1945 the UN War Crimes Commission called for a war crimes court or tribunal because of the inevitability of penalties for crimes against humanity. ${ }^{2} \mathrm{Ne}-$ vertheless, nor the London Assembly nor the UN Commission finalized long-standing issue of individual criminal responsibility under international law for crimes against humanity committed not only during war but also in peacetime. ${ }^{3}$ Moreover, the Commission was about to overview a proposal to punish those who committed crimes against the civilian population of the occupied territories. ${ }^{4}$ The Nuremberg Tribunal, set up for this purpose, was a contributor to international humanitarian law in the sentencing of those convicted of war crimes and other international crimes. The tribunal's jurisdiction includes war crimes, crimes against peace and crimes against humanity. Article 6 of the Statute of the Nuremberg Tribunal uses the phrase "violations of the laws and customs of war." The analysis of the act lets us consider that the usual war takes place mainly between the warring parties and it is conducted by combatants. However, when violations are committed against those who are not directly involved in the war and are subjected to violence, these acts may constitute war crimes because they can not be justified via the concept military necessity. According to the Charter, war crimes include violating the laws or customs of war, killing, torturing, enslaving or otherwise abducting civilians in the occupied territories, killing or torturing prisoners of war or naval personnel, killing hostages, looting public or private property, meaningless destruction of towns and villages, looting and other acts not related to military necessity. Thus, the Charter defines the scope of the term "war crimes" very generally. "War crimes" can be understood as a general term meaning a violation of international humanitarian law

(C) A.V. Allahverdiyev, 2020

* Аловсат Вілаєт Аллахвердієв, кандидат юридичних наук, викладач Бакинського державного університету 
applicable during an armed conflict. ${ }^{5}$ So, war crimes are an independent type of international crimes, they involve all serious violations of the customs and laws of war, most importantly the killing or injury of non-combatants, the enslavement and deportation of civilians, and the neglect of cities, villages and towns without military necessity. covers demolition or devastation. These actions may include acts of genocide if they take place in the context of war. ${ }^{6}$

It can be argued that war crimes only cover acts enshrined in the 1949 Geneva Conventions for the Protection of Victims of War. Yet, we should not forget that these acts consist of only a fraction of war crimes, ones what are the most dangerous and serious. War crimes are specified in the charters of international criminal justice bodies in accordance with the norms of international law. For example, Article $6 \mathrm{~b}$ of the Statute of the Nuremberg International Military Tribunal, Articles 2-3 of the Statute of the Yugoslav Tribunal, and Article 4 of the Statute of the Rwanda Tribunal, Article 8 of the Rome Statute of the International Criminal Court explain the nature of war crimes. To sum up all the normative frameworks, I can say that war crimes is a broad legal category, covering serious violations of international humanitarian law in times of armed conflict, both international and non-international. Each of these violations is in itself a specific criminal act and gives rise to international criminal liability. ${ }^{7}$

In general, I may classify the acts covered by the term "war crime" in a narrower sense refering to a violation of the laws or customs of war what may include:

- Serious violations of the Geneva Conventions or their Additional Protocols;

- Violation of the Hague Conventions;

- Violation of the laws and customs of war.

Nevertheless, this general approach to war crimes does not provide details to understand the very depth of the concept. It is obvious that war crimes could be related to other types of international crimes, but distinct features are needed to spesify precise scope of war crimes. The term "war crime" in the broadest sense means that all those who act in violation of international law in connection with armed conflict may be prosecuted and punished. Of course, this does not exclude a direct connection with crimes against peace, crimes against humanity and genocide. Since "war crimes" are violations of the laws and customs of war, it is necessary to show all the elements of this category of crimes in order to get a complete picture of war crimes. There are certain acts that constitute war crimes, which are not directly referred to as "war crimes" in the Charter of the Nuremberg Tribunal or in the 1949 Geneva Conventions and the 1977 Additional Protocols. After Nuremberg and the Far Eastern International Tribunal, the norms of war crimes are more clearly reflected in the Charter of the Yugoslav Tribunal, the international criminal tribunal established for the events of the former Yugoslavia and establishing responsibility for war crimes. The Charter of the Yugoslav Tribunal states that the main goal is to bring to justice those responsible for violations of international humanitarian law, to prevent possible crimes, to bring justice to thousands of victims and their families in the former Yugoslavia, and to establish peace in the former Yugoslavia. To address such issues, the Yugoslav Tribunal brought to justice those convicted of war crimes as a result of their investigations.

Throughout history, most war crimes have gone unpunished. The trial of Peter von Hagenbach, first tried in a special tribunal for war crimes in 1474, was one of the world's first international crime trial, as well as the first trial of a person responsible for his subordinates' orders. ${ }^{8}$ During the trial, he claimed that he had simply carried out his orders, but the court ignored him and ruled, and Hagenbach was beheaded. Later, in 1865, Henry Wirz, an army officer, was convicted by a military tribunal of torture to death in Andersonville Prison during the American Civil War. ${ }^{9}$ Despite the military tribunals set up after World War II and the last two international criminal trials for the former Yugoslavia and Rwanda, these crimes have not been prevented in an absolute manner. This form of trial suggests that it is reasonable to assume that many of the perpetrators of inhumane acts during the war will not be punished for their actions in future. In other words, we are morally obliged to change our attitude and methodology of prosecution. It should be noted that the establishment of international criminal tribunals and the prosecution of military and political leaders have to some extent prevented the ongoing crimes, while the tribunals have created confidence in the international community that criminals will not go unpunished. Clearly, the Charter of the Nuremberg Tribunal, which contained acts of war crimes, was intended to punish the organizers and perpetrators of World War II as well as introduce clear regulations for the international humanitarian law. International humanitarian law, an important institution of international law, recognizes the existence of armed conflict because it accepts that wars cannot be prevented or stopped in general, but we may restrict the methods and means of war. Thus, the standardization of the rules of war was determined in two directions:

- The first is the Geneva Legislation (Geneva Conventions), based on the four Geneva Conventions of 1949, in Geneva, and the two 1977 Protocols attached to it.

- The second direction is the Hague legislation, which includes a number of conventions signed in the Hague in 1899 and 1907.

Geneva law regulates the interaction of legal regimes to protect different classes of people, especially the defenseless, non-combatants and prisoners of war, in armed conflict. The Hague law, on the other hand, regulates the methods and techniques of warfare. The Geneva Conventions for the first time defined some "grave violations" of the laws of war as war crimes, which give rise to individual criminal liability. ${ }^{10}$ It is precisely these factors that have become one of the priorities of modern international law, and have begun to expand and develop. mmediately after the end of World War II, the Nuremberg Tribunal was established because it was so important to hold the Nazi regime and its key leaders accountable for the war of aggression. The purpose of the tribunal was to formally condemn and ban Nazism, to put an end to one of the threats that could lead to a new world war in the future. For about a year, the International Military Tribunal has done a great job. The trial lasted ten months in Nuremberg. During the trial, 403 public hearings were held, 116 witnesses were questioned, more than 300,000 written statements were made, and about 3,000 documents were examined, and 12 Nazi criminals were executed. ${ }^{11}$ The Nuremberg trials were followed by the Tokyo trial. This court was established to punish Japanese militarists. The Potsdam Declaration 
of July 26, 1945, called for the trial of those accused of war crimes. Japan's act of surrender of September 2, 1945, considered the obligation to "conscientiously abide by the terms of the Potsdam Declaration," including the punishment of war criminals. In addition to the statutes of the Nuremberg and Tokyo tribunals, the rules on war crimes are set out in the Draft Code of Crimes against the Peace and Security of Mankind, the Charter of the Yugoslav Tribunal and the Statute of the International Criminal Court.

The Yugoslav Tribunal was established by UN Security Council Resolution 827 to try four groups of crimes such as serious violations of the Geneva Conventions, violation of the laws and customs of war, genocide, crimes against humanity. Since its inception, the Tribunal has indicted 161 people; The last indictment was issued in December 2004, the last was approved and opened in the spring of 2005. Goran Hadzic was last arrested on July 20, 2011. The Charter of the Yugoslav Tribunal contains two different articles on war crimes (Article 2-3). Article 2 lists serious violations of the 1949 Geneva Conventions, and Article 3 lists "specific violations of the laws and customs of war." This distinction is related to the division of international humanitarian law into two parts - the protection of human rights in armed conflict ("Geneva law") and the restriction of methods and means of warfare ("Hague law"). According to Article 27 of the 4th Geneva Convention, the rape of civilians is formally illegal, but there is a gap in the regulation of "serious offenses" contained in Article 147. For these reasons, the systematic sexual assault of 200,000 Bangladeshi women by Pakistani soldiers in 1971 went unpunished. ${ }^{12}$ Moreover, similar acts occured in 1995 in Haiti during Cedras's rule committed by the military, mostly by the FRAPH (Front for the Progress and Development of Haiti), again there was not serious mechanisms of punishment arranged by UN mission. ${ }^{13}$

In comparison with the above-mentioned cases, the Yugoslav Tribunal considered such cases to be war crimes, as well as crimes against humanity on a large scale and as a premeditated tactical target. In the actions of several Serbian battalions, the rape of Muslim women in groups and in public was intended to intimidate and discourage the local population, as well as to intimidate the birth of a newly-established Chetnik (Serbian Chetniks are a Serbian national guerrilla movement). The tribunal was the first to hear a war crime case against a Serbian police officer who was involved in the violence against Muslim women prisoners in a "rape camp" in Foka and turned a blind eye to the abuses. Of course, it is important to emphasize that these actions, investigated by the tribunal, are not the violence of individual women, which is condemned by the international community, but the fact that sexual assault is carried out in the form of ethnic cleansing. There have been several arguments of in-depth analysis in summary of the decisions. Bosnian Serb criminals were allowed to rape Muslim women in public in order to humiliate them in front of their neighbors and fellow prisoners in the camp. The Serbs wanted to put a cultural mark on the victims of the aggression. It is not only the act that makes sexual violence a war crime, but also the fact that it is allowed or committed for political purposes. In 1992, there were political motives in Bosnia for committing acts such as forced pregnancies, which in no way could be justified in any way, and which infringed on moral values. This, of course, was a step towards changing the ethnic composition of the population. For this reason, the Yugoslav Tribunal supported the investigation. The tribunal was criticized for paying too much attention to violence. The tribunal did not find it necessary to provide convincing evidence of racism or political motives in certain cases. In Celebici case, for example, it was clear that the judiciary tended to define rape as torture, regardless of the motive. ${ }^{14}$

It was also interesting to note that this did not apply to the rape of a man, but to a woman. Of course, such an approach would not be correct. It is especially dangerous when an immoral act is committed in a systematic and political manner, which is a crime against humanity, but can also be described as a war crime. Tadic, who is known for his atrocities against Bosnian Muslims, said in his trial that two individuals could be charged with rape based on the words of an anonymous prosecutor, but that this was a fundamental violation of the right to a fair trial. Gradually, such mistakes were eliminated. Mass sexual violence, which was uncommon in the early stages of the Bosnian conflict, has not been repeated, and the international community is beginning to realize that such acts of human dignity, ethnic cleansing in the form of public policy, extend beyond the country and undermine international peace and security.

The Court of Appeals of the Yugoslav Tribunal was somewhat reluctant to accept that Article 2, which covered "serious violations" of the Geneva Conventions, could only be applied in the context of an international armed conflict. At that time (1949), the Geneva Conventions were not so influential, the traditional law was not yet perfect enough to allow the world community to bring to justice the leaders of any country who organized armed uprisings and committed inhumane atrocities. As if to emphasize this chronological error, the Chamber of Appeals argued that most of Article 3, which deals with violations of the laws and customs of war, does not apply to internal armed conflict. He justified this by saying that the perpetrators of the conflict, on behalf of both the state and the rebels, must be held accountable under international law for respecting "fundamental norms of humanity." The International Court of Justice came to the same conclusion in the 1986 Nicaragua-US conflict. Due to the significant conflict between the behavior condemned by the Geneva Convention (Yugoslav Tribunal Charter, Article 2) and the traditional law of war (Yugoslav Tribunal Charter, Article 3), the difference between traditional law is that one declares jurisdiction over another to do has already lost its resilience. Historically, as the Chamber of Appeals has pointed out, there has been a complete contrast between the state of war, which reflects the armed conflict between sovereign states, and the rebels within a sovereign state.

First, international law turned a blind eye to the violation of the territorial integrity of the state, or rather to the civil conflict of the insurgents. It was time to put an end to undesirable conflicts. Thus, "the approach to the sovereignty of the state has been gradually replaced by the approach to the person. The principle that "all laws were created for the benefit of man", which is the basis of Roman law, has also gradually become a permanent reference in the international community. This is based on the fact that the difference between an interstate war and a civil war in the field of armed conflict loses its value as a factor in people's lives. Thus, there was a difference in the approach to the internal armed conflict and the international armed conflict. As it reaches the level of an armed conflict, when 
determining the application of international humanitarian law to a special situation, the question immediately arises: is the conflict in question international in nature?

Article 2 of the Geneva Conventions of 1949 states that even if no state of war is declared in one or more of the Parties to the High-Level Treaty, it shall not constitute a declaration of war or any other armed conflict between the parties. international armed conflicts. Such a definition requires that both Parties to the High Level Treaty be brought to a state of military readiness. However, there is a difference between an international conflict and an international one or a conflict involving multiple partner states. After the events of September 11, 2001, when the United States, along with its coalition allies, fought the Taliban and its allies, the conflict in Afghanistan began as an international armed conflict. According to Article 2, this conflict was considered "international" if it was between two or more states. As soon as Hamid Karzai's government came to power, the struggle between the two sovereign states came to an end. According to the Geneva Conventions, the conflict was not considered an international armed conflict at that time, although the troops of many countries remained internationalized due to their involvement in the conflict. Therefore, the application of most of the articles of the Geneva Conventions to this conflict is technically impossible. Whether the conflict was of a domestic or international nature, the key fact was the outbreak of war. It is a kind of war crimes.

In their approach to international armed conflict and non-international armed conflict, experts rightly do not accept a different approach to the elimination of violations in both cases. They note that at a time when two sovereign states are at war with each other and armed violence is taking place "exclusively" in the territory of a sovereign state, and yet these states are reluctant to impose the same prohibitions or provide the same protection, to protect civilians from violence by warring parties. Why ban sexual harassment, torture, and the unjustified destruction of hospitals, churches, museums, or private property, as well as the illegal declaration of weapons that injure innocent people?"15 If they are banned, then there is no need for a different approach to dealing with the consequences of international and non-international armed conflicts. Another useful feature in the classification of conflicts is conflicts that appear to be non-international armed conflicts because the state's military forces are fighting insurgents or rebel groups, but with significant state intervention. The situation in the former Yugoslavia is an example of this. The armed conflict here began as a classic civil war, with armed confrontation between ethnic groups in Yugoslavia. As a result, however, the union republics, including Bosnia and Herzegovina, declared their independence.

Determining where and when international humanitarian law would be applied was a matter for two special international tribunals to determine. In both the former Yugoslavia and Rwanda, prosecutors have accused individuals of committing war crimes for atrocities far beyond the scope of active hostilities. For example, in one of the general issues raised by the tribunal against the jurisdiction of the tribunal, Tadic argued that the war crimes clauses mentioned in the indictment should be repealed, citing the fact that he did not commit his actions during the armed conflict. Tadic made history at the end of the twentieth century with a lawsuit that defined the scope and principles of international criminal law.

He represents a large section of Bosnian Serbs who are outside the army and who have "fulfilled their obligation" to kill, deport and torture Muslims, and then become the culprits of the society of which they were former members. There is no doubt about Tadic's guilt: he was well known in the town, and the evidence of witnesses who knew him from the Omarska death camp was very close to the truth. He took an active part in ethnic cleansing by arresting Muslim civilians, beating men and boys apart from women and the elderly, and then assisting in the deportation of women and the elderly. He worked part-time as a traffic policeman and, although not a regular soldier, was allowed to roam the nearby Omarska camp, where Muslim men and boys were being held. Here he enjoyed the brutal beating and torture of prisoners. Her name was also mentioned in the atrocities committed in the women's camp of Trnopolye. All indications are that he was a member of the "firing squads" that executed Muslims during this period. Punishment is an example of collective responsibility rather than individual criminal responsibility. This central problem affected the decision of the Chamber of Appeals on 26 January 2000 to sentence Tadic. The chamber had to make concessions to Tadic's criminal activities: "His actions have a small share in the team structure compared to those committed by higher-ranking officials or ideologues and authors of the policy of ethnic cleansing." He was sentenced to a maximum term of twenty years and a minimum term of imprisonment of ten years.

From the point of view of judicial practice, Tadic's case is important in determining the preconditions of international humanitarian law. First of all, there should be an "armed conflict", that is, not "banditry, unorganized, shortlived uprisings or terrorist activities", but a different intense conflict between the organized parties. Second, the prosecution must prove that there is a sufficient link between the charge of a crime against humanity and an armed conflict. Third, when the charge is related to war crimes under the Geneva Convention, it must be further established that the armed conflict is of an international nature and that the victims are persons protected by the Geneva Convention.

The court acquitted Tadic because, according to the evidence in front of them, Milosevic was not the supervisor and commander of the Bosnian Serbs. However, the Chamber of Appeals focused on one issue and stressed that the fact that Milosevic trained his Bosnian Serb allies and provided them with food and ammunition provided sufficient support. This was enough to "internationalize" the conflict, thereby enforcing the "serious offenses" clause of the Geneva Convention. Many of Tadic's crimes were in conflict with the "war customs and traditions" that apply to all armed conflicts, both international and local. While upholding the charges, the Yugoslav Tribunal called for the application of international humanitarian law in a specific situation, referring to the application of international humanitarian law in the event of an armed conflict, as well as the territorial scope of the sanctions imposed. The tribunal concluded that although the Geneva Conventions did not provide for the geographical scope of international armed conflicts, some of the provisions of these conventions were applicable not only in the areas of actual hostilities, but throughout the territory of the parties to the conflict. In particular, the provisions on the treatment of prisoners of war and other hostages of the opposing side have nothing to do with the proximity to the actual war zones. 
In general, international legal instruments and literature state that the laws and customs of war apply only to inhumane acts closely related to armed conflict. Various factors have been taken into account by international courts to determine whether the actions of the accused are closely linked to the armed conflict:

- the fact that the perpetrator is a fighter;

- the victim is a protected person under the Geneva Conventions or Annex I Protocol;

- the victim is a member of the armed forces of the opposite party;

- the circumstances of the crime;

- whether the crime was committed with the assistance of the parties to the conflict or in secret;

- and the fact that the crime was committed by officials.

We may appreciate that the Yugoslav Tribunal has made great strides, likening it to a light in a dark tunnel. These are the successes that:

- "Transition from impunity to responsibility", which until recently was the only judicial crime committed in the context of the Yugoslav conflict, because prosecutors in the former Yugoslavia did not want to commit such crimes at all;

- "Fact-finding", which contains a large amount of information about the fact that the tribunal has resolved the case and its long-term consequences;

- "Ensuring the justice of thousands of victims and their right to vote", which represents the majority of witnesses before the court;

- "Achievement in International Law", which describes the concretization of a number of concepts of international law that are not governed by Nuremberg;

- "Strengthening the Rule of Law", which discusses the role of the Tribunal in promoting the application of international standards in war crimes in the former Yugoslav republics.

By prosecuting officials convicted of war crimes, the tribunal has shown that no one can escape his crimes by using his official powers, and must be brought to justice. The trials of Milan Martic, President of the Serbian Administration (Croatia), and Radovan Karadzic, President of the Bosnian Serb Administration, and Ratko Mladic should be considered. ${ }^{16}$

During the siege of Sarajevo, Bosnian Serb snipers and their agents launched a systematic campaign to deliberately target civilians. A large number of civilians have been killed and injured since April 1992. Deliberate attack on civilians is a violation of the laws or customs of war. The killing and wounding of these civilians by sniper fire is a crime against humanity. Between May 26, 1995, and June 2, 1995, under the leadership and control of Radovan Karadzic and Ratko Mladic, 284 UN peacekeepers were captured in many locations. Radovan Karadzic and Ratko Mladic were charged with violating the laws or customs of war and gross violations of the Geneva Conventions. Between May 24 and August 30, 1992, Serbian forces illegally captured more than 3,000 Bosnian Muslims and Bosnian Croats from the Prijedor region (Bosnia-Herzegovina in northwestern Bosnia and Herzegovina) and detained them in the Keraterm "camp." Detainees were killed, sexually assaulted, tortured, beaten, and otherwise brutally and inhumane treated at an old ceramics factory and in a warehouse just outside the town of Prijedor. The camp guards and others who came to the camp were regularly subjected to physical violence, constant humiliation, degradation, inhumane treatment, and fear of death. Hundreds of prisoners were killed. Some of the accused were found dead. A room full of at least 140 prisoners was shot dead by machine guns and heavy weapons.

In addition, there were many critics of the tribunal. It was noted that not all of those accused of war crimes were prosecuted, only government officials. However, the number of war criminals was innumerable. The most high-profile case before the tribunal was Milosovic and Radovan Karadzic, the leader of Bosnia and Herzegovina. For the first time, the Danish public observed the process of bringing a country's political leadership to international criminal responsibility. Of course, this can be considered a success of international law.

The international community has adopted two additional protocols to the Geneva Convention in response to changes in the nature of the armed conflict, the dominance of non-international armed conflicts, the movement of the battlefield to densely populated areas, the expansion of civilian participation in armed conflicts and the escalation of guerrilla warfare. Most importantly, Protocol 1 provided a broader definition of international armed conflict, including "armed conflicts in which people exercise their right to self-determination and fight colonial rule, foreign occupiers and racist regimes." Protocol 2 specifies the minimum provisions of Article 3 . Historically, states have been reluctant to adopt legal regulations governing non-international armed conflicts, fearing that opposition or insurgent groups will be legitimized in the first place, and that issues considered as domestic problems will fall into the hands of international charters and investigations. During the drafting of the four Geneva Conventions, representatives of the International Committee of the Red Cross and a number of countries proposed more detailed regulations for non-international armed conflicts. The result of this sharp resistance was a compact 3rd general substance. The following section of Protocol 2 shows that there is a growing public support for the settlement of conflicts that do not fall within the scope of the Geneva Conventions.

Article 8 of the Rome Statute deals with war crimes and states that armed conflict is defined as either international (or between states) or non-international (generally between or between non-state actors such as insurgent groups). is. and non-state actors such as). In total, there are 74 war crimes listed in Article 8. However, the most serious crimes relate only to serious violations of the 1949 Geneva Conventions and only to international conflicts and serious violations of Article 3 of the 1949 Geneva Conventions. years applied to non-international conflicts. The commission of any of the acts prohibited by Article 1 is a war crime and the perpetrators must be brought to justice. In general, according to the authors of research in this field, war crimes, which are considered a special type of international law, have a number of features (violation of the laws and customs of war; accompanied by military violence against civilians and human security; non-compliance; international legal liability for its commission). ${ }^{17}$ 
Conclusion. As a result of the above noted, I can say that war crimes is still one of the challengeable topics of international law. The definition of war crimes raises serious questions of scope and appropriate methods of prosecution. I think that the current study of war crimes combines life-long problems related to the detection, analysis and punishment in international level. In this regard, the proper development of the institution of war crimes justifies the general effectiveness of international law. Recent armed conflicts demonstrate that war crimes get relatively new types and forms. On the other hand, making perpetrators liable is becoming hard due to the political assumptions. And finally, traditional overview of war crimes does not let us to follow crucial rules of international humanitarian law.

I may propose war crimes to be divided into four categories. The two categories are crimes committed during international armed conflicts, and the other two categories are crimes committed during non-international armed conflicts. The fact that acts committed during non-international armed conflicts are also considered war crimes should be seen as a step forward in law. The acts provided for in the international documents as war crimes are mainly those that have been described as serious violations of the Geneva Conventions and their Additional Protocols. At the same time, acts that are not considered as serious violation of international humanitarian law, also may be described as war crimes. For example, the recruitment of children into the armed forces, the resettlement of their citizens in the occupied territories, and the deportation of people from the occupied territories can be studies as war crimes described in international legal instruments. In addition, the use of chemical, bacteriological, nuclear weapons, or unreasonable delays in the repatriation of prisoners of war and civilians, and non-selective attacks to the detriment of civilians and civilian objects, which are considered war crimes, are not reflected in the Statute as war crimes.

The public danger of war crimes is the emergence of an indefinite number of people who choose to earn money in exchange for their participation in military conflicts and operations, which results in the destruction of not only the military forces of the conflicting parties, but also many civilians. Due to the fact that military operations are conducted between the armed forces of the conflicting parties, civilians should not be subjected to any violence in accordance with international law. Violence against civilians is not an acceptable way to win. Civilians should not be involved in hostilities, they should be respected in all cases as well as their rights and freedoms whould be ensured. When the security of the civilian population or reasonable military considerations requires it, the occupying power may carry out complete or partial evacuation from a certain area. At the time of such evacuations, wards may be relocated only within the occupied territories. However, this is an exception when it is not possible in practice. Those evacuated in this way must be returned to their places as soon as the fighting in the area is over.

${ }^{1}$ Bassiouni C.M. Crimes against humanity: historical evolution and contemporary application. USA, New York: Cambridge University Press. 2011. 884 p. P. 138.

2 El Zeidy M.M. The principle of complementarity in international criminal law: origin, development and practice. The Netherlands, Leiden: Koninlijke Brill. 2008. 368 p. P. 71.

3 Schabas A.W. War Crimes and human rights: essays on the death penalty, justice, and accountability. UK, London: Cameron May Ltd. 2008. 1158 p. P. 725.

${ }^{4}$ Schabas A.W. Genocide in international law: the crimes of crimes. $1^{\text {st }}$ edition. UK, Cambridge: Cambridge University Press. 2000. 644 p. P. 31.

5 Huseynov L.H. International law. Coursebook. Azerbaijan, Baku: “Ganun” Publishing. 2000. 368 p. P. 210.

${ }^{6}$ Allahverdiyev A.V. Crimes against humanity in international law. Handbook. Azerbaijan, Baku: "Elm ve tehsil” Publishing. 2017. 376 p. P. 71.

7 ICRC IHL Database - Customary IHL. Practice Relating to Rule 156: definition of war crimes. https://ihl-databases.icrc.org/ customary-ih1/eng/docs/v2_cou_ca_rule156

8 Bantekas I., Nash S. International criminal law. $3^{\text {rd }}$ edition. UK, Abingdon: Taylor\&Francis. 2009. 637 p. P. 495.

9 Tobin T.B. True crime in the Civil War: cases of murder, treason, counterfeiting, massacre, plunder and abuse. USA, Mechanisburg: Stackpole Books. 2012. 320 p. P. 240.

${ }_{10}$ Ronald C.S., Beth V. S. International criminal law: the essentials. USA, New York: Aspen Publishers. 2008. 384 p. P. 274.

11 Shepova N.Y. Nuremberg trials: history and modernity. Official website of the Ministry of Defense of Russian Federation http://mil.ru/winner_may/history $/$ more.htm?id=12079489\%40 cmsArticle

12 Robertson G.R. Crimes against humanity: the struggle for global justice. UK, London: Penguin Books. 2006. 800 p. P. $199-200$.

13 Krause J., Ronzitti N. The EU, the UN and collective security: making multilateralism effective. USA, New York: Routledge. 2012. 296 p. P. 59.

14 Segal M.T., Demos V. Gendered perspectives on conflict and violence. Part A. UK, Bingley: Emeral Group Publishing. 2013. 308 p. P. 201.

15 Supra note 10. P. 237.

16 UN ICTY. Milan Martic, Radovan Karadzic and Ratko Mladic indicted along with 21 other accused. The Hague, 25 July 1995 https://web.archive.org/web/20150414184203/http://www.icty.org/sid/7237

${ }^{17}$ Aliyev A.I. Azerbaijan in the target of international crimes: legal analysis. Azerbaijan, Baku: "Nurlar" Publishing House. 2018. 170 p., p. 101. http://www.ebooks.az/book_RGZ3Vq17.html намі.

Аллахвердієв А.В. Визначення військових злочинів: погляд на судове переслідування міжнародних судових орга-

Стаття присвячена огляду обсягу і застосування міжнародного кримінального переслідування за військові злочини. Хоча термін «військові злочини» не $є$ новим поняттям у міжнародному праві, існують різні підходи для визначення його точних кордонів. Військові злочини завжди розглядаються як одна 3 основних задач і особливостей, які зводять до мінімуму всю ефективність міжнародного права. Проте, не всі відомі судові переслідування за військові злочини закінчилися успіхом. Сучасний тип міжнародного судового переслідування за військові злочини може бути пов'язаний із військовими трибуналами, створеними після Першої світової війни. Ми повинні розуміти, що, будучи одним із видів міжнародних злочинів проти миру і людства, 
військові злочини можуть бути вчинені за межами активного періоду війни. Таким чином, необхідно заново визначити масштаби і предмет військових злочинів. 3 іншого боку, судове переслідування за військові злочини має вивчатися окремо від інших порушень міжнародного права, зокрема прав людини.

Ключові слова: міжнародне право, міжнародні порушення, військові злочини, судові органи, міжнародні злочини, юрисдикція, суд, міжнародний кримінальний суд, міжнародне гуманітарне право.

\section{Резюме}

Аллахвердиев А.В. Определение военных преступлений: взгляд на судебное преследование международных судебных органами.

Статья посвящена обзору объема и применения международного уголовного преследования за военные преступления. Хотя термин «военные преступления» не является новым понятием в международном праве, существуют различные подходы для определения его точных границ. Военные преступления всегда рассматриваются как одна из основных задач и особенностей, сводящих к минимуму всю эффективность международного права. Тем не менее, не все известные судебные преследования за военные преступления закончились успехом. Современный тип международного судебного преследования за военные преступления может быть связан с военными трибуналами, созданными после Первой мировой войны. Мы должны понимать, что, будучи одним из видов международных преступлений против мира и человечества, военные преступления могут быть совершены за пределами активного периода войны. Таким образом, необходимо заново определить масштабы и предмет военных преступлений. С другой стороны, судебное преследование за военные преступления должно изучаться отдельно от других нарушений международного права, в частности прав человека.

Ключевые слова: международное право, международные нарушения, военные преступления, судебные органы, международные преступления, юрисдикция, трибунал, международный уголовный суд, международное гуманитарное право.

\section{Summary}

Alovsat Allahverdiyev. Defining war crimes: a look to the prosecution by international criminal judicial bodies.

The article is dedicated to the overview of the scope and application of international prosecution on war crimes. Although the term "war crimes" is not a new concept in international law, different approaches exist in defining the precise limits of it. War crimes are always considered as one of the primary challenges and pecularities minimizing the whole efficiency of international law. Nevertheless, not all known prosecutions on war crimes ended with success. In traditional international law war crimes are always related to military or armed conflicts what may be international or non-international conflict. History of international humanitarian law demonstrates that almost all of the military conflicts were associated with war crimes. However, international law was not able to buil up strong judicial mechanisms for the prosecution of war crimes for a long time. Modern type of international prosecution over war crimes can be linked to military tribunals established after World War I. At the same time, we should not forget that most of war crimes committed before and during WWI still remain unpunished. These problems demand new conceptual approach to the understanding of war crimes as well as methodology of international prosecution. We know that first military tribunals were of quasi-international character. Although modern international law contains fully international military tribunals, still there are a lot of cases of failure to punish war crimes. We need to understand that being a type of international crimes against peace and humanity, war crimes can be committed outside the active period of war. Thus, there is a need to re-define again the scope and subject matter of war crimes. On the other hand, prosecution of war crimes should be studied apart from other international law violations, human rights in particular.

Key words: international law, international violations, war crimes, judiciary, international crimes, jurisdiction, tribunal, international criminal court, international humanitarian law.

DOI: $10.36695 / 2219-5521.2 .2020 .85$

УДК 341.171: 341.24

\section{O.B. БАЗОВ}

Олександр Вікторович Базов, кандидат юридичних наук, докторант Інституту міжнародних відносин Київського національного університету імені Тараса Шевченка*

ORCID: 0000-0001-5763-1653

\section{ПИТАННЯ ПРАВОВОГО СТАТУСУ СПЕЦІАЛІЗОВАНОГО СУДУ ПО КОСОВУ}

Постановка проблеми. У сучасних умовах активного розвитку системи міжнародного кримінального правосуддя від Нюрнберзького і Токійського воєнних трибуналів та згодом - міжнародних кримінальних трибуналів по колишній Югославії та Руанді у полі зору науки міжнародного права перебувають міжнародні кримінальні судові органи так званої «нової хвилі», або «третього покоління», дослідження правових і інституційних засад яких становить значний науковий та практичний інтерес. До зазначених судових органів слід віднести і спеціалізований суд щодо розслідування воєнних та інших міжнародних злочинів, що були вчинені на території колишньої СФРЮ в Косові в 90-х рр. ХХ ст. під час збройного конфлікту, жертвами якого стала велика кількість громадян, більшість із яких - цивільні особи. Оскільки зазначений Суд було утворено за активної

(C) О.В. Базов, 2020

* Olexandr Bazov, Ph.D. in Law, Doctoral Candidate of the Institute of International Relations of Taras Shevchenko National University of Kyiv

Часопис Київського університету права • 2020/2 